\title{
CONSUMER BEHAVIOUR ON THE MEDIA MARKET
}

\author{
M. Přibyl, L. Stejskal, O. Dufek, K. Ondrášková
}

Received: June 26, 2009

\begin{abstract}
PŘIBYL, M., STEJSKAL, L., DUFEK, O., ONDRÁŠKOVÁ, K.: Consumer behavior on the media market. Acta univ. agric. et silvic. Mendel. Brun., 2009, LVII, No. 6, pp. 225-234

The paper deals with a correlation between factors identifying a household representative and frequency of media usage. Particularly it concentrates on the analysis of internet and daily press usage. Internet is a constantly developing communication channel which is increasingly used in the field of marketing communication and contributes to the development of business environment. Due to its characteristics it is an ideal mean for multilingual communication and communication on international markets. The daily press is on the other hand a representative of traditional media. It is perceived by public as a more natural communication channel. The paper seeks an answer to the question which communication channel is more suitable to communicate with a particular target group - press or the internet. The paper tests the correlation between identification factors and frequency of internet and press presence. Testing will be carried out by using a database obtained in a primary research conducted by the Department of Marketing and Trade at the Faculty of Business and Economics, Mendel University in Brno. Results published in the paper are part of research objective, id. code: 6215648904 "The Czech Republic in the process of integration and globalization and the evolution of agrarian and service sectors in the new conditions of the European integrated market", thematic area 03 "The evolution of trade relationships regarding changes in a life style and purchasing behaviour and changes of business environment in the process of integration and globalization" that is conducted with a financial support of Ministry of Education, Youth and Sports.
\end{abstract}

media, correlation testing, consumer behaviour, consumer identification criteria, contingency analysis

\section{INTRODUCTION}

The paper deals with an evaluation of a correlation between household representative identification criteria and frequency of media usage. The authors assume consumer information channels to be of two types - electronic channels and classic channels. A typical representative of classic media is daily press. Electronic media are defined as media spread by analog or digital signals that are later converted to a form interpretable by a receiver. Among these media we include the radio, television, computers and subsequently the internet, in some cases intranet. The internet, particularly, is the most dynamic and fastest developing medium and for this reason it represents electronic media in this paper.

\section{OBJECTIVE AND METHODOLOGY}

The objective of this paper is to confirm or eventually disconfirm hypotheses claiming the existence of dependance of demographic identification factors of household representatives and frequency of gathering information from daily press or the internet. The attention is paid primarily to a detection of higher dependance of a group regarding press consumption eventually internet consumption. Based on these information it is possible to formulate predictions and recommendations when choosing the type of media having the optimal incidence to a particular group of consumers and their households.

Data used in analyses were obtained in the primary survey conducted by the Department of Mar- 
keting and Trade, Faculty of Business and Economics, Mendel University of Agriculture and Forestry in Brno. Nearly 2500 of respondents took part in the survey. Respondents were asked several questions concerning consumer behaviour characteristics, among others the attitude to media.

To express a structure of groups and frequency of opinion statements it was used a specific depiction of two-dimension contingency table. Data matrix n x 2 was assumed. The category variable $A$ is having $\underline{r}$ values (categories) $a_{1}, a_{2}, a_{3} \ldots a_{r}$; category variable $B$ is having s categories, $b_{1}, b_{2}, b_{3} \ldots b_{s}$.

Indeed: $n_{i j}(i=1,2 \ldots r ; j=1,2 \ldots, s)$ are absolute composite occurrences (frequencies);

$n_{i}$ are real absolute occurrences (frequencies);

$n_{j}$ are column absolute occurrences (frequencies).

The table analysis is based on the capability of each cell to be addressed a frequency value that would occur in case that both examined characters are independent - it means the occurrence (frequency) value is determined as following:

$$
n_{i j}^{\prime}=\frac{n_{i} n_{i}}{n} .
$$

Contrary to observed (absolute) occurrences it also has values different from integral values. From its nature we can also derive the more differences in observed and computed frequencies the higher the dependance of characters. Measuring of differences in data (as well as measuring of dependance) sorted to two-dimension contingency tables by probability sampling is lead through square contingency:

$$
\chi^{2}=\sum_{i=1}^{r} \sum_{j=1}^{s} \frac{\left(n_{i j}-n_{i j}^{\prime}\right)^{2}}{n_{i j}^{\prime}} .
$$

As a measurement of dependance intensity of category variables was selected the Pearson correlation coefficient:

$$
C_{p}=\sqrt{\frac{\chi^{2}}{\chi^{2}+n}}
$$

Where: $\chi^{2}$ is Pearson statistics

$$
\chi^{2}=\sum_{i=1}^{r} \sum_{j=1}^{s} \frac{\left(n_{i j}-n_{i} \cdot n_{\cdot_{j}} / n\right)^{2}}{n_{i} \cdot n_{\bullet_{j}} / n},
$$

that in case of independence has zero value; for given $\underline{r}$ and $\underline{s} \chi^{2}$ has n.h maximum value, where:

$$
h=\min (r-1, s-1) .
$$

Accordingly, the Pearson correlation coefficient has maximum value that is variable:

$$
\max \left(C_{p}\right)=\sqrt{h /(h+1)}<1 .
$$

For interpretation it is more often used the ratio $\mathrm{C}_{\mathrm{p}} / \max \left(\mathrm{C}_{\mathrm{p}}\right)$ belonging to the interval 0-1.

When testing the dependency it was observed whether the value of the test criterion exceeds the critical level which is represented by fractile $\chi^{2}-$ division with the scope $\gamma=(r-1)(s-1)$. If so, at the selected level we reject the zero hypothesis claiming independence of characters and we consider dependance of qualitative characters as proved.

\section{RESULTS AND DISCUSSION}

It is obvious the life style, the way of spending a leisure time and the way of receiving information are changing. These changes are reflected by a relatively new communication medium - the internet. If we take a look into a short history of the internet, we see the internet has become a user friendly communication channel providing adequate information. The time of the internet being strictly segmented environment has been forgotten.

In the Table I we see the average daily sold printings of the daily press in the Czech Republic during the period 1996 to 2006. Throughout the Czech market there are six national titles and one consolidated regional title that remained stable during this decade. In this paper we leave aside the fact that up to the year 2000 the regional press was published by different publishers and later united as brands Deníky Bohemia a Deníky Moravia belonging to the company Vltava-Labe-Press. Uniting process finished in 2006 by introducing the single brand Deník marked with a particular geographic inherence. Three daily papers ceased and two popular papers were newly established during the period under

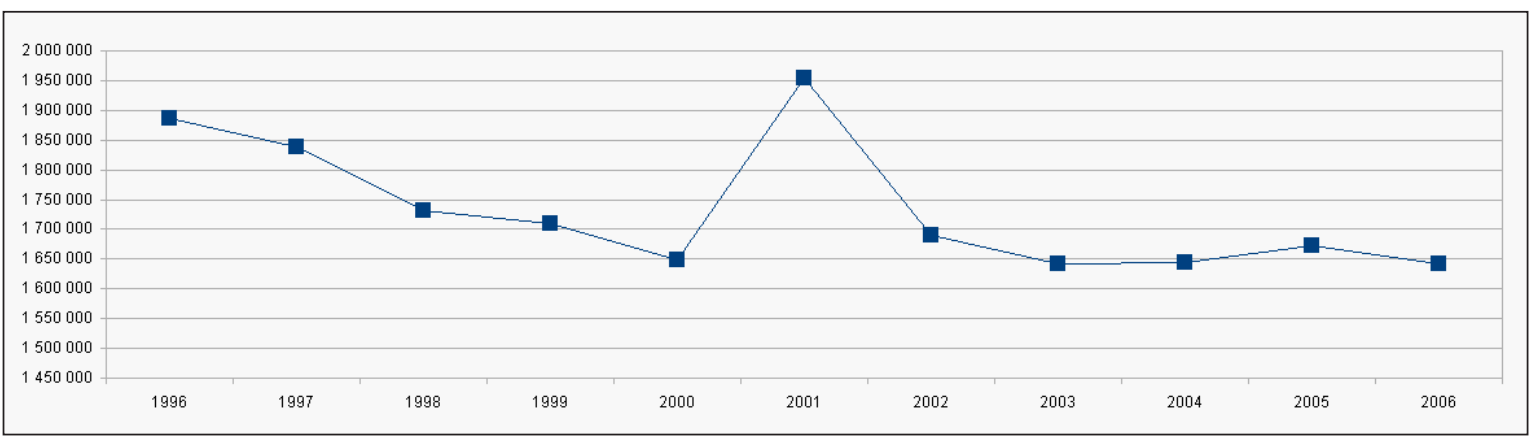

Source: ABC ČR - Audit Bureau of Circulations, member of IF ABC

1: Trend in average daily sold printings of the daily press in the Czech Republic 
consideration. One brand in the sphere of popular press went through the phase of establishment and cessation during this period.

Fig. 1 represents the trend in average daily sold printings of daily press in the Czech Republic. In the years 1996-2000 average daily sold printings were decreasing - from the number of 1886068 sold issues per day in 1996 to 1709012 sold issues per day in 2000. It indicates that sales decreased by $9.34 \%$.

In 2001 we observe significant rise in a number of sales to 1954217 issues per day. The rapid rise (by $18.46 \%$ ) sources from the merger of regional press to one product offering a common national part and from the enter of the new popular paper Super which has brought a competition for the popular paper Blesk - up to this time Blesk had been the only popular paper brand operating on the Czech market.
The daily paper Super has taken the market position of a real smear-sheet and this first extraordinary paper has attracted the attention of readers. In 2002, due to the rising popularity of smear-sheets two of the serious sheets ceased and a number of sold printings of other serious sheets decreased. Super has also experienced decrease in sales. The readers switched to the popular sheet Blesk. Blesk approached Super by changing the orientation and content of the sheet. In the first year after the merger of regional press the sales significantly declined (by 13, 24\% in a year). In 2003 Super ceased for two reasons. First, the competition of Blesk was too strong; second, the other papers become popularized. Since 2003 the trend in average daily sold printings of the daily press is slightly decreasing (with exception of 2005 - in this year the smear-sheet Šíp was introduced). Compared to 1996, in 2006 the average

I: Sold printings in Czech republic from 1997 to 2006

\begin{tabular}{|c|c|c|c|c|c|}
\hline \multirow{2}{*}{ Title } & \multicolumn{5}{|c|}{ Average daily sold printings by issues } \\
\hline & 1997 & 1998 & 1999 & 2000 & 2001 \\
\hline Aha! / Aha! TV & 0 & 0 & 0 & 0 & 0 \\
\hline Blesk/ Blesk magazín & 242216 & 241956 & 283620 & 329207 & 332979 \\
\hline Hospodářské noviny / IN magazín / Víkend & 111912 & 97314 & 86074 & 77471 & 75395 \\
\hline Lidové noviny / Pátek LN & 62251 & 74920 & 82117 & 91371 & 105051 \\
\hline Mladá fronta DNES / Magazín Dnes+TV & 362778 & 364728 & 353991 & 338996 & 337988 \\
\hline Práce & 53571 & 0 & 0 & 0 & 0 \\
\hline Právo / Dům \& Bydlení / Magazín Práva & 258354 & 241148 & 249217 & 220434 & 212808 \\
\hline Regionální deníky VLP - SOUHRNNÝ NÁKLAD & 457225 & 450131 & 412666 & 377746 & 520645 \\
\hline Slovo & 87269 & 73766 & 59811 & 48310 & 40833 \\
\hline Sport / Sport magazín & 63512 & 52239 & 59783 & 61255 & 60959 \\
\hline Super & 0 & 0 & 0 & 0 & 179789 \\
\hline Šíp & 0 & 0 & 0 & 0 & 0 \\
\hline Zemské noviny & 139486 & 135743 & 121733 & 104847 & 87770 \\
\hline SUM & 1838574 & 1731945 & 1709012 & 1649637 & 1954217 \\
\hline \multirow{2}{*}{ Title } & \multicolumn{5}{|c|}{ Average daily sold printings by issues } \\
\hline & 2002 & 2003 & 2004 & 2005 & 2006 \\
\hline Aha! / Aha! TV & 0 & 0 & 0 & 0 & 90762 \\
\hline Blesk/ Blesk magazín & 378477 & 458295 & 514499 & 524595 & 476892 \\
\hline Hospodářské noviny / IN magazín / Víkend & 74634 & 74112 & 66764 & 63476 & 62797 \\
\hline Lidové noviny / Pátek LN & 91031 & 79086 & 72272 & 69884 & 72634 \\
\hline Mladá fronta DNES / Magazín Dnes+TV & 312077 & 309602 & 308486 & 299889 & 303355 \\
\hline Práce & 0 & 0 & 0 & 0 & 0 \\
\hline Právo / Dům \& Bydlení / Magazín Práva & 205096 & 194913 & 180537 & 170583 & 162875 \\
\hline Regionální deníky VLP - SOUHRNNÝ NÁKLAD & 451717 & 462828 & 432589 & 403629 & 344073 \\
\hline Slovo & 0 & 0 & 0 & 0 & 0 \\
\hline Sport / Sport magazín & 58588 & 63218 & 69570 & 69408 & 66504 \\
\hline Super & 117813 & 0 & 0 & 0 & 0 \\
\hline Šíp & 0 & 0 & 0 & 70400 & 61572 \\
\hline Zemské noviny & 0 & 0 & 0 & 0 & 0 \\
\hline SUM & 1689433 & 1642054 & 1644717 & 1671864 & 1641464 \\
\hline
\end{tabular}

Source: ABC ČR - Audit Bureau of Circulations, member of IF ABC 
daily sold printings of the daily press in the Czech Republic declined by $12.97 \%$.

World Association of Newspapers (WAN) claimed that global newspaper sales were up 2.1 percent over the year 2004. Unlike previous years, growth was not only driven by gains in developing markets, but increases in sales in many mature markets.

According to Timothy Balding, the Director General of the Paris-based WAN: "We have come to expect big circulation gains in developing countries, but it has been a very long time since we saw such a revival in so many mature markets. Newspapers are clearly undergoing a renaissance through new products, new formats, new titles, new editorial approaches, better distribution and better marketing."

"Despite the incredible competitive challenges in the advertising market, newspapers have more than held their own and their revenues are strongly on the increase again," he said. WAN claims in 2004 more than 395 million people buy a newspaper every day, up from 374 million in 1999. The five largest markets for newspapers are: China, with 93.5 million copies sold daily; India, with 78.8 million copies daily; Japan, with 70.4 million copies daily; the United States, with 55.6 million; and Germany, 22.1 million. Sales increased in China, India and Japan in 2004 and declined in the U.S. and Germany.
We can also observe the declining trend in average daily sold printings of the daily press in Germany. Germany being the closest western country influences the course of events in the Czech Republic. That is one of the reasons why Germany is often interpreted as a comparative country. The other reason is Germany's recent historical evolution when the western and eastern parts of Germany united. Nowadays, Germany comprises characteristics of purely western country and purely ex eastern-block country.

In the last decade, the press market in Germany is declining (see Fig. 2). We expect the same trend in the Czech Republic. However, the lower internet availability in the Czech households results to the later oncoming of this trend. The internet availability in the Czech households is half compared to Germany while Germany is above the EU average by $4 \%$ (see Fig. 4).

It is striking that the number of households having at least one computer is only few percentage points lower in the Czech Republic than in Germany (see Fig. 3) as well as Germany being under the EU average. According to the Markent company, the number of individuals not using the internet is declining in the Czech Republic (see Fig. 5).

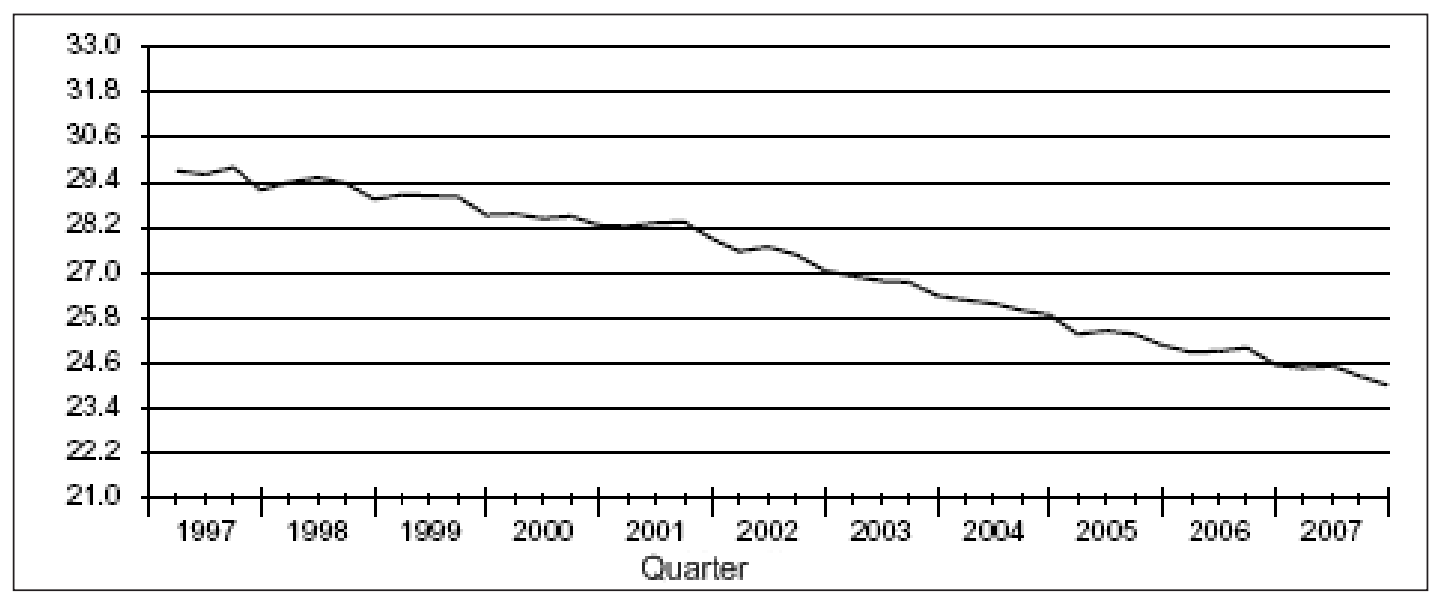

Source: INFORMATIONSGEMEINSCHAFT ZUR FESTSTELLUNG DER VERBREITUNG VON WERBETRÄGERN E.V.

2: Trend in average daily sold printings of the daily press in Germany

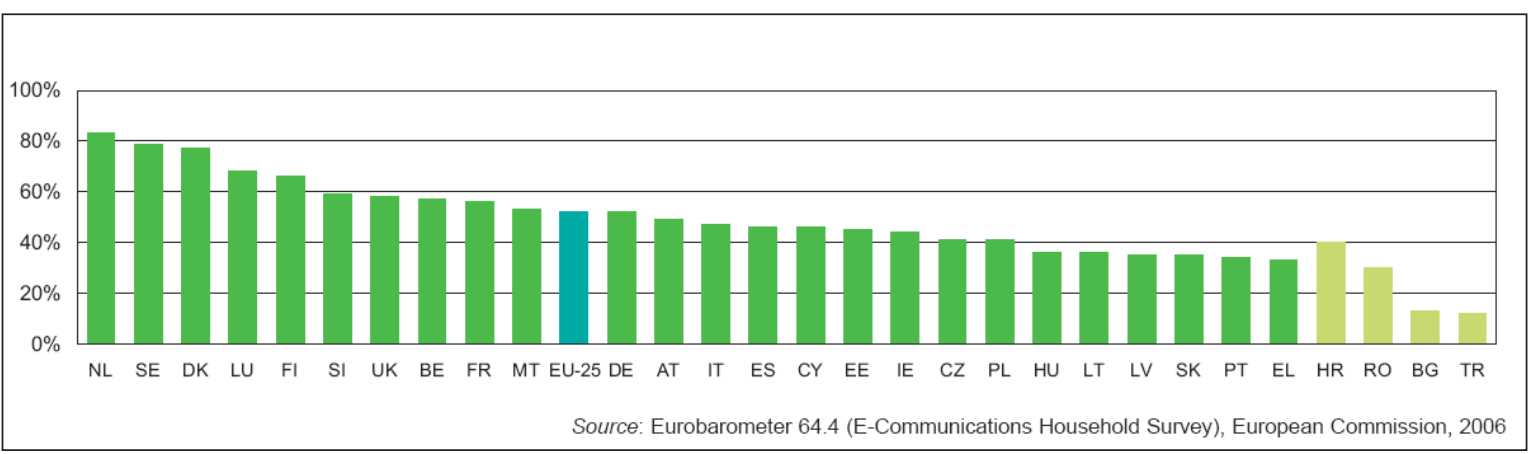

3: Percentage of households having at least one computer, 2006 


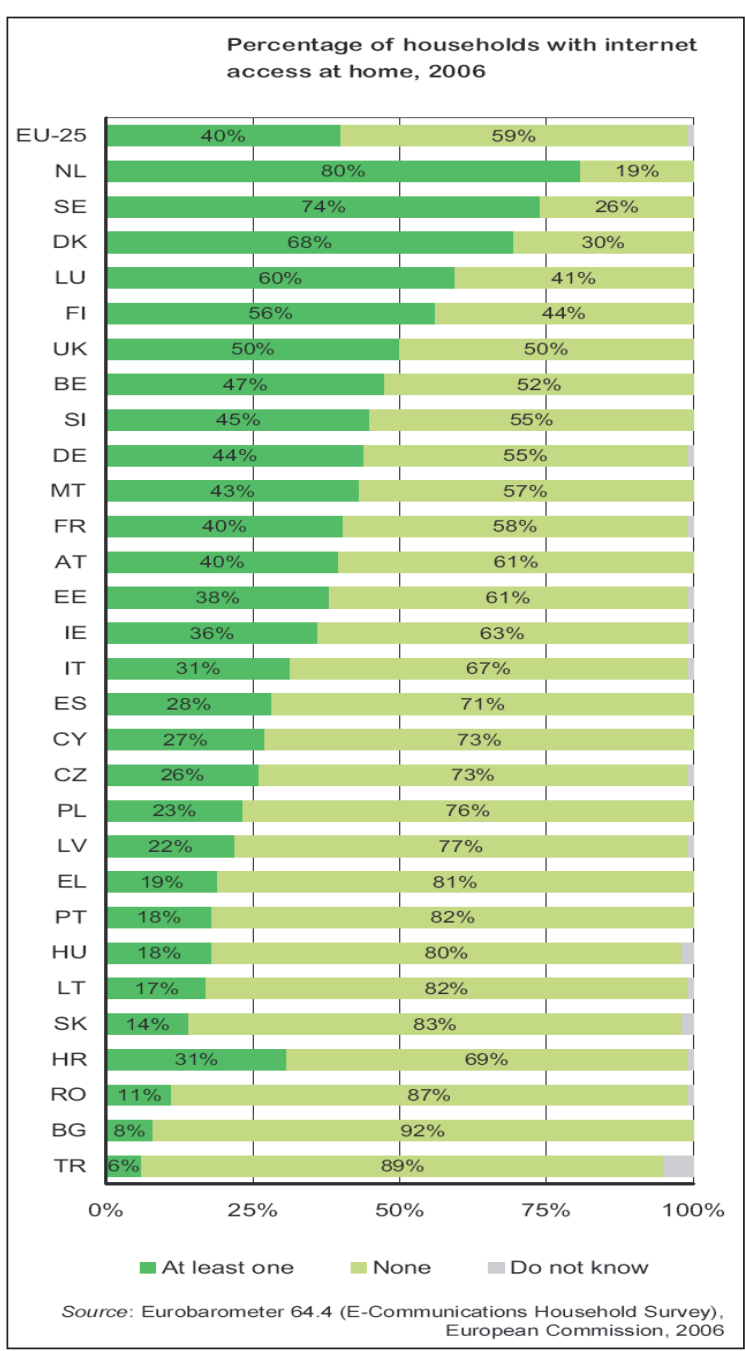

4: Percentage of households with internet access at home, 2006

As a part of survey respondents were questioned about the frequency of internet usage by the household representative. $46 \%$ of respondents use internet daily, $22 \%$ use internet few times a week and $10 \%$ use internet less than once a week. $6 \%$ of respondents use internet once a week and the rest $16 \%$ do not use internet at all (see Fig. 6).

However, classic sources of information are not losing their importance, particularly the daily press.
The typical feature of today's media market is the integration of previously independent producers to bigger media groups. In terms of the Czech Republic and European Union we do not talk about national alliances but multinational media giants that control many national companies. In this case we talk about horizontal integration since stronger editors absorb smaller independent competitors because of their weak market position.

One of the examples arising on the Czech market is the case of the VLP, a. s. - editorial group. This company gradually integrated all the regional editors to the one group with joint capital. This trend is most apparent when talking about press though it affects all types of media.

When conducting the survey, $37 \%$ of respondents stated they read newspaper daily as a part of their daily routine, $9 \%$ of respondents read newspaper less than once a week, $4 \%$ do not read newspaper at all, 17\% read newspaper once a week and 33\% buys newspaper few times a week. Answers are illustrated by the Fig. 7 .

The analysis of presented facts regarding to the highest level of education of the household representative revealed following:

Square contingency value is 174,4091 . This indicator does not show dependance intensity of the characters therefore the Pearson coefficient was computed for frequency of internet usage and the highest level of education of the household representative. The coefficient is equal to 0,4399 which shows the existence of dependance even if dependance is not significant.

To verify the statement it is necessary to set the hypothesis claiming characters that were analyzed are mutually independent. Pearson's classification fractile $c_{p}^{2}$ for the level of education is 26.3 (number of grades of free scope is 16). The hypothesis implying independence of education level as a demographic identification factor and frequency of internet usage can be rejected.

Table 3 shows percent of occurrence of answers about frequency of daily press reading.

When dealing with the table III, the square contingency is equal to 18,866 . Pearson coefficient is equal to 0.159 . We conclude there is only weak dependance between the level of education of the house-

II: Contingency table of respondent group classification according to education and internet usage

\begin{tabular}{|c|c|c|c|c|c|c|}
\hline \multirow[b]{2}{*}{ Highest level of education } & \multicolumn{6}{|c|}{ Frequency of internet usage } \\
\hline & Daily & $\begin{array}{c}\text { Few times } \\
\text { a week }\end{array}$ & Once a week & $\begin{array}{c}\text { Less than } \\
\text { once a week }\end{array}$ & Not at all & sum \\
\hline Primary & $0.83 \%$ & $0.14 \%$ & $0.00 \%$ & $0.14 \%$ & $1.10 \%$ & $2.20 \%$ \\
\hline Secondary - training college & $2.48 \%$ & $2.75 \%$ & $2.20 \%$ & $3.16 \%$ & $7.98 \%$ & $18.57 \%$ \\
\hline Secondary & $18.29 \%$ & $9.77 \%$ & $1.93 \%$ & $4.13 \%$ & $4.68 \%$ & $38.79 \%$ \\
\hline Tertiary-college & $1.38 \%$ & $0.69 \%$ & $0.55 \%$ & $0.14 \%$ & $0.41 \%$ & $3.16 \%$ \\
\hline Tertiary - university & $22.97 \%$ & $8.67 \%$ & $1.51 \%$ & $2.06 \%$ & $2.06 \%$ & $37.28 \%$ \\
\hline sum & $45.94 \%$ & $22.01 \%$ & $6.19 \%$ & $9.63 \%$ & $16.23 \%$ & $100.00 \%$ \\
\hline
\end{tabular}

Source: original survey 
III: Contingency table of respondent group classification according to education and daily press reading

\begin{tabular}{lrrrrrr}
\hline \multirow{2}{*}{ Highest level of education } & \multicolumn{5}{c}{ Frequency of daily press reading } \\
\cline { 2 - 7 } & Daily & $\begin{array}{c}\text { Few times } \\
\text { a week }\end{array}$ & Once a week & $\begin{array}{c}\text { Less than } \\
\text { once a week }\end{array}$ & Not at all & sum \\
\hline Primary & $0.55 \%$ & $0.41 \%$ & $0.69 \%$ & $0.41 \%$ & $0.14 \%$ & $2.20 \%$ \\
Secondary - training college & $6.74 \%$ & $7.02 \%$ & $3.30 \%$ & $0.96 \%$ & $0.55 \%$ & $18.57 \%$ \\
Secondary & $13.07 \%$ & $12.65 \%$ & $7.70 \%$ & $3.44 \%$ & $1.93 \%$ & $38.79 \%$ \\
Tertiary - college & $1.51 \%$ & $0.96 \%$ & $0.14 \%$ & $0.28 \%$ & $0.28 \%$ & $3.16 \%$ \\
Tertiary - university & $15.41 \%$ & $11.83 \%$ & $5.09 \%$ & $3.44 \%$ & $1.51 \%$ & $37.28 \%$ \\
sum & $37.28 \%$ & $32.87 \%$ & $16.92 \%$ & $8.53 \%$ & $4.40 \%$ & $100.00 \%$ \\
\hline
\end{tabular}

Source: Original survey

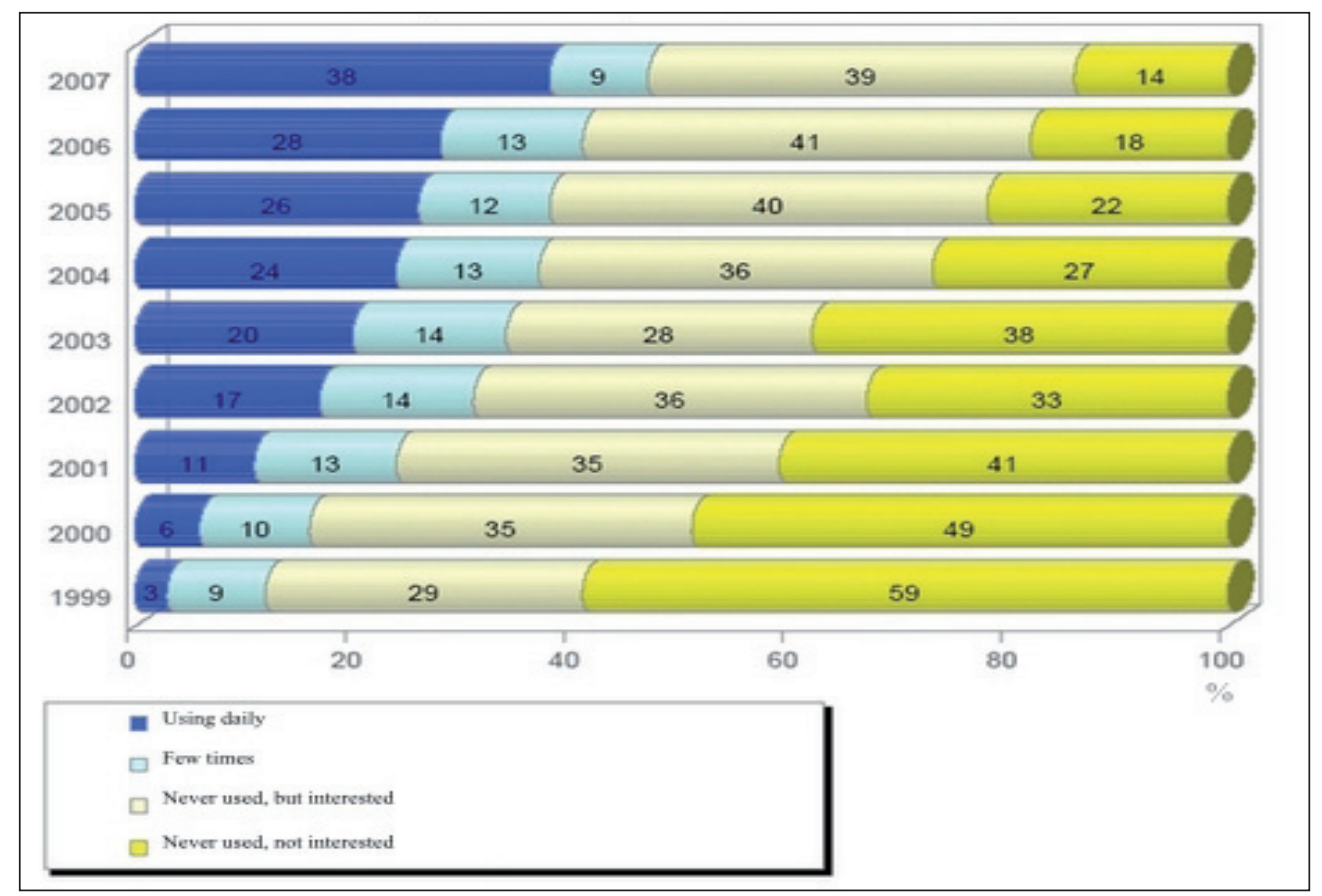

Source: Markent

5: Using the internet by individuals 1999-2007

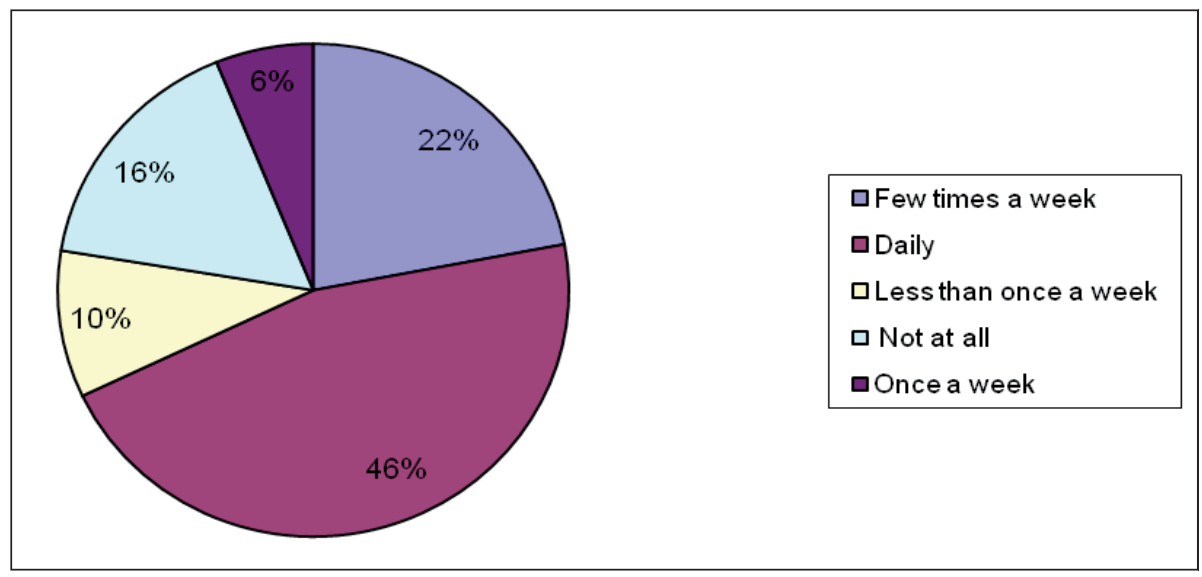

Source: original survey

6: Frequency of internet usage by the household representative 


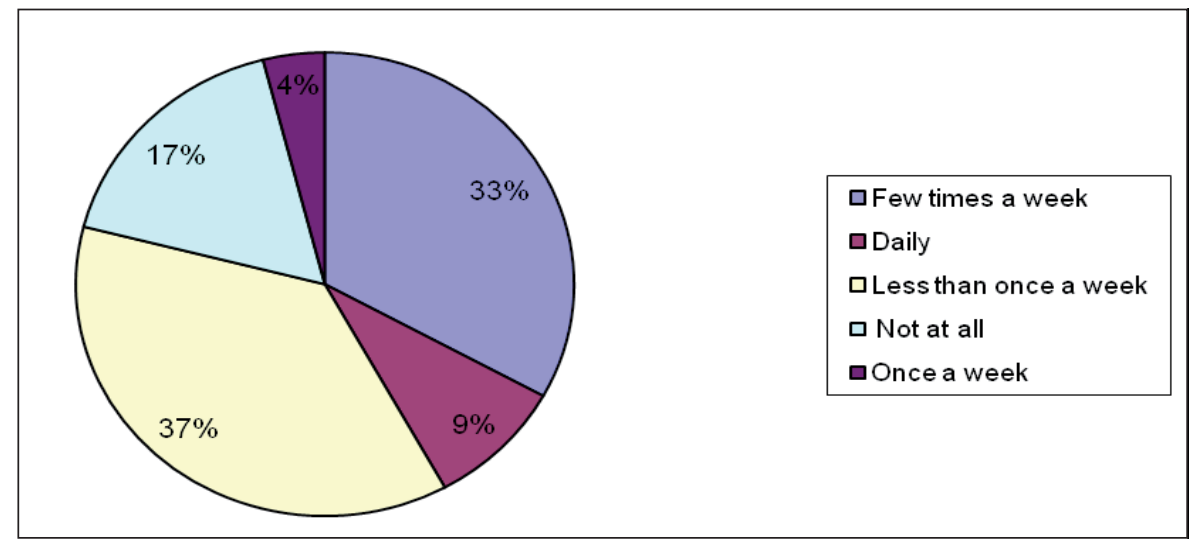

Source: original survey

7: Frequency of newspaper reading by household representative

hold representative and frequency of daily press reading. This conclusion may be predicted by monitoring the percent occurrence throughout the lines of the table that are more or less corresponding. There is a divergence when dealing with the primary education category. Here we have to consider the relatively small number of respondents ( $2.2 \%$ of the total number of respondents). If we set the hypothesis claiming independence of both characters then regarding 16 grades of free scope the Pearson's classification fractile $c_{p}^{2}$ is equal to 23.6.

The hypothesis implying independence cannot be rejected.

Authors conclude the segmentation while targeting marketing communication pays off in the matter of electronic media - which means the internet. Messages put through the internet should be adjusted to the group of well-educated consumers while the daily press offers a bigger chance to target a group of consumers characterized by primary or secondary training education.

In the following text we deal with comparison of preferred information media in relation to the profession of the household representative is following

Square contingency is equal to 145.4762. Pearson correlation coefficient is equal to 0.4083 - weak mutual dependance was found. To verify this statement we set the hypothesis claiming independence of analyzed characters. Pearson's classification fractile $c_{p}{ }^{2}$ is equal to 41.3 (28 grades of free scope) which implies we can reject this hypothesis.

Square contingency is equal to 34.9519. Pearson correlation coefficient is equal to 0.2142 - mutual dependance was found. However, dependance is very weak. Even if we set the hypothesis claiming independence of analyzed characters then for 28 grades of free scope the Pearson's classification fractile $c^{2}$ is equal to 41.34 which implies we cannot reject this hypothesis at the given level of importance.

We again conclude the penetration of classic media is deeper. The impact of daily press is mass. The advantage of publishing through web sites is the opportunity of good targeting. It is possible to target particular groups - namely students, working students, employees and entrepreneurs. These groups answered twice more often that they follow internet news daily compared to the answer that they follow it few times a week. The correlation between a size of municipality and frequency of internet usage shows the table VI.

Square contingency is equal to 55.2184. This indicator again does not show the level of intensity

IV: Contingency table of respondent group classification according to profession and internet usage

\begin{tabular}{lrccccc}
\hline \multirow{2}{*}{ Profession } & \multicolumn{5}{c}{ Frequency of internet usage } \\
\cline { 2 - 7 } & Daily & $\begin{array}{c}\text { Few times } \\
\text { a week }\end{array}$ & Once a week & $\begin{array}{c}\text { Less than once } \\
\text { a week }\end{array}$ & Not at all & sum \\
\hline employed & $28.61 \%$ & $14.44 \%$ & $3.99 \%$ & $6.46 \%$ & $9.63 \%$ & $63.14 \%$ \\
self-employed & $3.85 \%$ & $2.48 \%$ & $1.51 \%$ & $1.38 \%$ & $1.93 \%$ & $11.14 \%$ \\
entrepreneur & $5.78 \%$ & $2.48 \%$ & $0.69 \%$ & $0.28 \%$ & $0.83 \%$ & $10.04 \%$ \\
agriculturist & $0.14 \%$ & $0.14 \%$ & $0.00 \%$ & $0.14 \%$ & $0.28 \%$ & $0.69 \%$ \\
pensioner & $0.28 \%$ & $0.41 \%$ & $0.00 \%$ & $0.69 \%$ & $3.30 \%$ & $4.68 \%$ \\
working student & $3.03 \%$ & $0.28 \%$ & $0.00 \%$ & $0.00 \%$ & $0.00 \%$ & $3.30 \%$ \\
student & $3.44 \%$ & $0.83 \%$ & $0.00 \%$ & $0.14 \%$ & $0.28 \%$ & $4.68 \%$ \\
other & $0.83 \%$ & $0.96 \%$ & $0.00 \%$ & $0.55 \%$ & $0.00 \%$ & $2.34 \%$ \\
sum & $45.94 \%$ & $22.01 \%$ & $6.19 \%$ & $9.63 \%$ & $16.23 \%$ & $100.00 \%$ \\
\hline
\end{tabular}

Source: original survey 
of dependence therefore we calculate the Pearson correlation coefficient which equals to 0.2756 . The dependance exists but it is very weak. To verify the hypothesis implying the independence we calculate the Pearson's classification fractile $c^{2}$ which is equal to 26.30 (16 grades of free scope). We can reject the hypothesis. The correlation between a size of municipality and frequency of daily press reading shows the table VII.

Square contingency is equal to 13.1370. Pearson correlation coefficient is equal to 0.1344 . The dependance between the two characters is very weak. We can say it is almost nonexistent. To follow the methodology of this paper we set the hypothesis claiming independence and we again consider 16 grades of free scope and the Pearson's classification fractile $c_{p}^{2}$ which is equal to 26.3. It is obvious the hypothesis cannot be rejected.

When talking about frequency of daily press reading, the size of municipality does not play any role. On the other hand, it plays an important role when talking about internet usage even if the importance is lower than we expected. More important than consumer preferences are technological aspects - the more populated municipality the higher availability of electronic services. However, it is not a barrier for effective targeting. Web sites should be aimed to the population of bigger cities (taking into account that we can expect gradual change in future).

V: Contingency table of respondent group classification according to profession and daily press reading

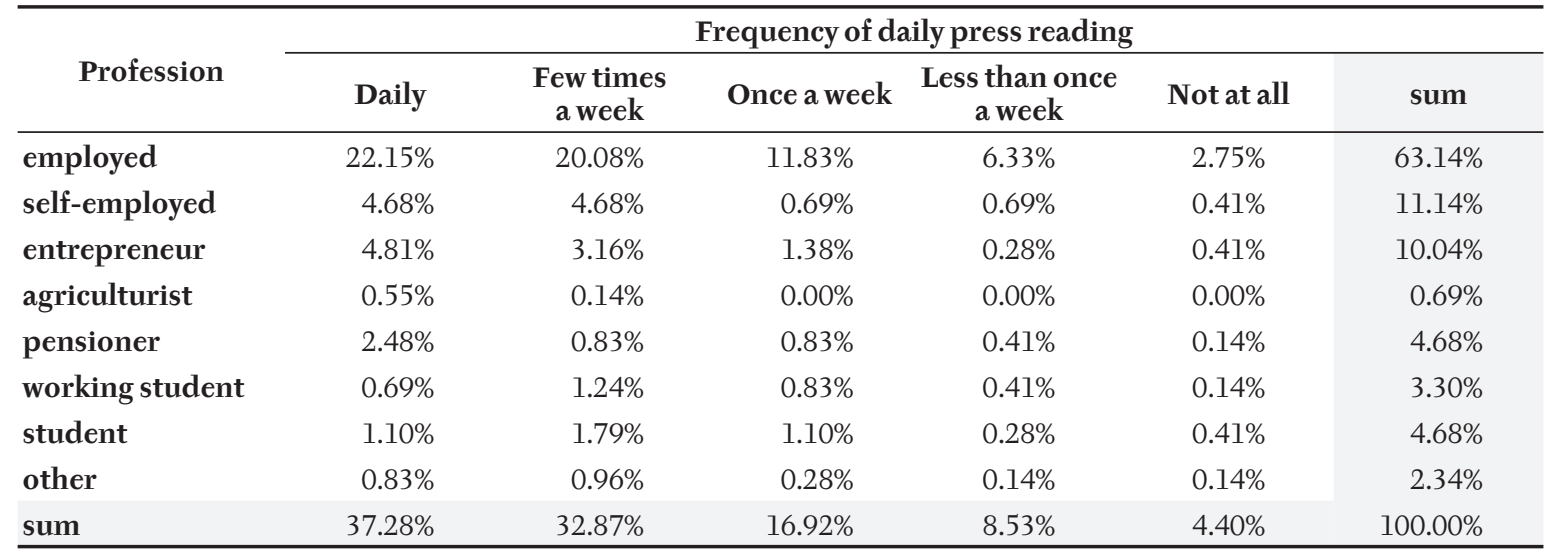

Source: original survey

VI: Contingency table of respondent group classification according to size of municipality and internet usage

\begin{tabular}{|c|c|c|c|c|c|c|}
\hline \multirow{2}{*}{$\begin{array}{c}\text { Size of municipality } \\
\text { (number of inhabitants) }\end{array}$} & \multicolumn{6}{|c|}{ Frequency of internet usage } \\
\hline & Daily & $\begin{array}{l}\text { Few times } \\
\text { a week }\end{array}$ & Once a week & $\begin{array}{c}\text { Less than } \\
\text { once a week }\end{array}$ & Not at all & sum \\
\hline $1001-10000$ & $9.90 \%$ & $6.46 \%$ & $1.65 \%$ & $2.89 \%$ & $5.64 \%$ & $26.55 \%$ \\
\hline $10001-70000$ & $9.90 \%$ & $5.09 \%$ & $0.96 \%$ & $1.93 \%$ & $3.16 \%$ & $21.05 \%$ \\
\hline over 200001 & $18.57 \%$ & $5.64 \%$ & $1.65 \%$ & $2.48 \%$ & $2.75 \%$ & $31.09 \%$ \\
\hline sum & $45.94 \%$ & $22.01 \%$ & $6.19 \%$ & $9.63 \%$ & $16.23 \%$ & $100.00 \%$ \\
\hline
\end{tabular}

Source: original survey

VII: Contingency table of respondent group classification according to size of municipality and daily press reading

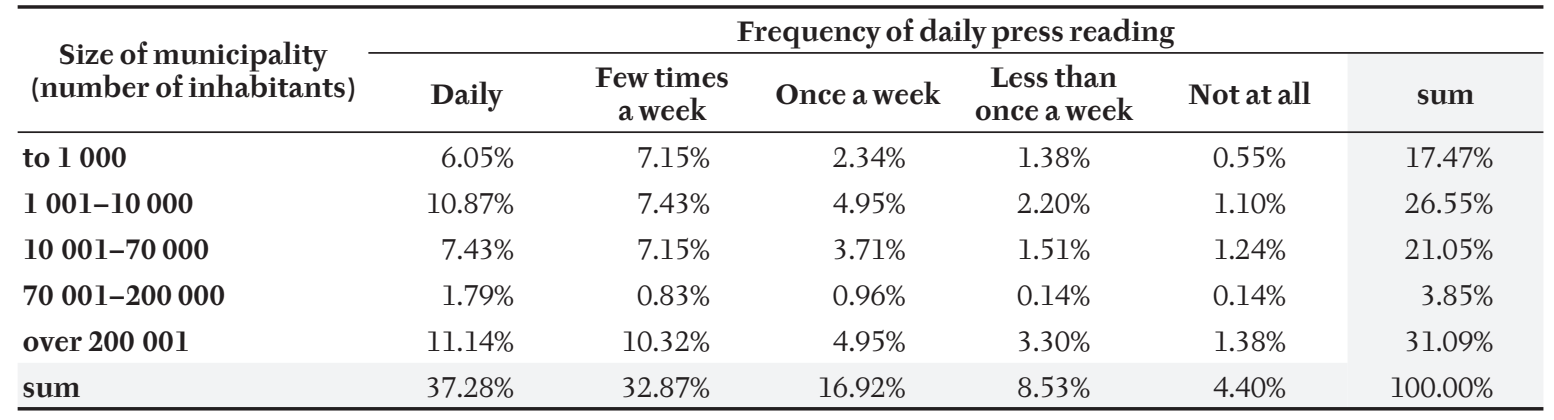

Source: original survey 


\section{CONCLUSION}

This paper comprises results of complex survey conducted to find out the potential of media impact on households - different consumer segments. Data were obtained by questioning 2500 respondents and testing dependance of identification characters and frequency of usage of different media.

We proved correlation between frequency of internet usage and all considered demographic characters. These characters are the size of municipality where the household resides, profession and education of a household representative. The internet offers effective targeting to people who reached tertiary education, students, working students, entrepreneurs and people living in relatively bigger cities (Czech cities having more than 200000 inhabitants).

Authors were dealing with analysing of percent occurrences of internet usage in relation to the level of income of a household. It is worth mentioning that dependance was proved. Targeting of middle and high level income groups appears to be the most effective. The paper is not devoted to this category in a detail since data has lost their interpretation value as a result of rapid pace of economic development.

On the other hand, dependance of identification factors and frequency of daily press reading was not proved in any case (considering also income groups). Authors conclude the mass coverage enables the effective targeting of specific demographic segments. Daily press is more suitable for mass market targeting.

Results published in the paper are part of research objective, id. code: 6215648904 "The Czech Republic in the process of integration and globalization and the evolution of agrarian and service sectors in the new conditions of the European integrated market", thematic area 03 "The evolution of trade relationships regarding changes in a life style and purchasing behaviour and changes of business environment in the process of integration and globalization" that is conducted with a financial support of Ministry of Education, Youth and Sports.

\section{SOUHRN}

\section{Chování spotřebitele na trhu s médii}

V př́ispěvku jsou zhrnuty dosavadní poznatky komplexního šetření ke zjištění potenciálu mediálního ovlivňování různých domácností, potažmo různých spotřebitelských segmentů. Data jsou získána z testování závislostí identifikačních znakủ a frekvence spotřeby jednotlivých typů médií uvedené 727 respondenty dotazníkových šetření.

Byla prokázána závislost mezi frekvencí využívání internetu a všemi uvedenými demografickými identifikačními znaky. Jsou jimi počet obyvatel sídelní obce, respondentské domácnosti, povolání a vzdělání vůdčího člena domácnosti. Informační sdělení na internetu budou nejefektivněji cílena na vysokoškolsky vzdělané osoby či osoby s vyšším odborným vzděláním, z pozice povolání na studenty, pracující studenty a podnikatele. Dále na obyvatele největších měst republiky (skupina nad 200 tis. obyvatel).

Autoři se zabývali i analýzami četností užitíinternetu ve vztahu k výši čistého ročního přijmu domácnosti. Není bez zajímavosti, že i zde se závislost podařilo prokázat a nejefektivněji se jeví působení na střední až vyšší př̌ijmové skupiny. Tato kategorie není ale dále rozebrána, nebot definované př́ijmové skupiny a potažmo výstupy těchto analýz ztratily během dvou let zkoumání, vzhledem k vysokému tempu ekonomického růstu a mezd, na relevantnosti.

Závislost identifikačních faktorů a frekvence četby denního tisku ale nebyla prokázána ani v jednom případě (platí i pro zmíněné př́ijmové skupiny). Autoři se domnívají, že vzhledem k absolutnímu pokrytí populace tímto médiem nelze bez dalšího upřesnění cílit na jednotlivé demografické segmenty. Klasické tištěné deníky jsou ale velmi vhodné pro plošné zasažení populace informačním sdělením. Výsledky zveřejněné v příspěvku jsou součástí výzkumného záměru, id. kód VZ: 6215648904 "Česká ekonomika v procesech integrace a globalizace a vývoj agrárního sektoru a sektoru služeb v nových podmínkách evropského integrovaného trhu", tematický směr 03 "Vývoj vztahů obchodní sféry v souvislosti se změnami životního stylu kupního chování obyvatelstva a změnami podnikového prostředí v procesech integrace a globalizace" realizovaného za finanční podpory ze státních prostředků prostřednictvím MŠMTT.

média, testování korelace, chování spotřebitele, kontingenční analýza, identifikační kritéria spotřebitelů 


\section{REFERENCES}

ABC ČR. Prodané náklady od roku 1993 [online]. [1993-2007] [cit. 2007-10-20]. Dostupný z WWW: <http://www.abccr.cz/tabgraf96-soucasnost/ tabprod_nak96_98.html $>$.

Consumers in Europe: Fact and figures on services of general interest. [s.l.]: [s.n.], 2007. 194 s. Dostupný z WWW: <http://epp.eurostat.ec.europa.eu/cache/ITY OFFPUB/KS-DY-07-001/EN/KS-DY-07-001-EN. PDF $>$. ISBN 978-92-79-04596-7.

FORET, M., STÁVKOVÁ, J., 2003: Marketingový výzkum - jak poznávat své zákazníky. 1. vyd. Praha: Grada Publishing. 160 s. ISBN 80-247-0385-8.

INFORMATIONSGEMEINSCHAFT ZUR FESTSTELLUNG DER VERBREITUNG VON WERBETRÄGERN E. V.. Werbeträgerdaten - Quartalsauflagen [online]. [1997] [cit. 2007-10-25]. Dostupný z WWW: <http://www.ivw.de/index.php?menuid $=37 \&$ reporeid $=10 \#$ tageszeitungen $>$.
Média [online]. [2006] [cit. 2007-04-11]. Dostupný zWWW: <http://cs.wikipedia.org/wiki/M\%C3\%A9dia>.

MINAŘÍK, B., 2000: Statistika I - popisná statistika, druhá část. 1. vyd. Brno: MZLU. 107 s. ISBN 80-7157-427-9.

MINAŘÍK, B., 1998: Statistika II. 1. vyd. Brno: MZLU. 144 s. ISBN 80-7157-197-0.

STÁVKOVÁ, J., DUFEK, J., 2002: Marketingový výzkum. Dotisk, 1. vyd. Brno: MZLU. 150 s. ISBN 80-7157-330-2.

TURČÍNKOVÁ, J., STEJSKAL, L., STÁVKOVÁ, J., 2007: Chování a rozhodování spotrébitele. Brno: MSD. 104 s. ISBN 978-80-7392-013-5.

World Press Trends: Newspaper Circulation and Advertising Up Worldwide [online]. [2004] [cit. 2008-03-03]. Dostupný z WWW: <http://www.wan-press.org/ article7321.html>.

Address

Ing. Martin Přibyl, Institut celoživotního vzdělávání, Mendelova zemědělská a lesnická univerzita v Brně, Zemědělská 5, 61300 Brno, Česká republika, e-mail: pribyl@mendelu.cz, Ing. Ladislav Stejskal, Ing. Ondřej Dufek, DiS., Ing. Klára Ondrášková, Ústav marketingu a obchodu, Mendelova zemědělská a lesnická univerzita v Brně, Zemědělská 1, 61300 Brno, Česká republika, e-mail: xstejsk4@mendelu.cz, xdufek@mendelu. cz,xondrask@mendelu.cz 